\title{
Biocatalysis of agro-processing waste by marine Streptomyces fungicidicus strain RPBS-A4 for cellulase production
}

\author{
Rajanikanth Akurathi ${ }^{1}$, Damodharam Thoti ${ }^{2 *}$ \\ ${ }^{1}$ Department of Biotechnology, Sri Venkateswara University, Tirupati, Andhra Pradesh, India, ${ }^{2}$ Department of Environmental Sciences Sri Venkateswara \\ University, Tirupati, Andhra Pradesh, India
}

\section{ARTICLE INFO}

Article history:

Received on: September 19, 2017

Accepted on: October 12, 2017

Available online: January 17, 2018

\section{Key words:}

Cellulase,

Streptomyces fungicidicus strain

RPBS-A4,

Agro-processing waste,

Solid-state fermentation

\begin{abstract}
The fundamental reason for this investigation is to lessen the production cost of cellulase by advancing the generation medium and utilizing an option carbon source such as agro-processing waste deposit. Streptomyces fungicidicus strain RPBS-A4 was subjected to fermentation medium with supplementation of agro-processing waste powder as a solid substrate for cellulase enzyme production. The impact of various process parameters was examined for increasing cellulase production. Cellulase was observed to be produced by S. fungicidicus strain RPBS-A4 using rice bran (5-6\%), as best substrate among the tested. Solid state bioprocessing increased the production of enzyme activity at temperature $-40^{\circ} \mathrm{C}, \mathrm{pH}-9.0$, inoculum size $-0.6 / 100 \mathrm{ml}$, incubation period $-96 \mathrm{~h}$, substrate concentration - $0.6 \mathrm{~g} / 100 \mathrm{ml}$, carbon source - maltose (1\%), and nitrogen source - yeast extract (1\%). Under these most favorable conditions, the highest activity $13.18 \mathrm{U} / \mathrm{ml}$ of cellulase was observed. The S. fungicidicus RPBS-A4 has been considered as the best cellulase producer in biocatalysis of agro-processing waste deposits.
\end{abstract}

\section{INTRODUCTION}

Products of agro-industrial practices result in the generation of numerous structural plant components such as groundnut shell, sawdust, paddy straw, rice bran, wheat bran and peels which are renewable, chiefly unexploited, and inexpensive. Partial decomposition of these solid wastes produces leachate and affects groundwater and land environment. It also causes a bad odor and increases the chance for pathogens which cause serious diseases to organisms. One of the most effortless methods for dealing with contamination issues is biocatalysis of these agro-processing wastes into cellulase enzyme [1]. The production of this enzyme has been examined in numerous filamentous fungi, despite the fact that a little work has been done on bacterial cellulase and a constrained consideration is being actinomycetes. Vinogradova and Kushnir [2] stated that actinomycetes are one of the important microbial communities responsible for cellulose degradation found abundantly in the plant cell walls. Literature survey revealed that some of the soil actinomycetes - Streptomyces lividans, Streptomyces albaduncus, Streptomyces reticuli, and Streptomyces sp. Strain M7a and strain M7b and Streptomyces sp. F2621 have just been accounted for creating extracellular endoglucanase altogether in upgraded culture

*Corresponding Author

Damodharam Thoti,

Department of Environmental Sciences

Sri Venkateswara University,

Tirupati - 517 502, Andhra Pradesh, India.

Email: thotidamodharam@yahoo.co.in media utilizing cellulose powder as substrate [3]. However, a detailed investigation on the development of this enzyme from Streptomyces species has been hindered.

Solid wastes are used as informants for the production of novel enzymes. This is one of the best methods for the management of solid waste in an experienced way. Solid state bioprocessing has more advantages than submerged state bioprocessing due to low capital investment, generalization of the fermentation media, minimized energy requirement, absence of multipart machinery, and enhanced product recovery [4]. Much of the cellulose in nature exists as waste material from agroprocessing industry in the form of husk, stalks, stems, and peels. Hence, to utilize these waste products and to develop a cheaper method for the production of cellulase enzyme for enzymatic degradation. The present study describes the production and optimization of cellulase by solidstate biocatalysis of agro-processing waste.

\section{MATERIALS AND METHODS}

\subsection{Microbial Strain}

The organism used in this study was Streptomyces fungicidicus strain RPBS-A4, which was reported as cellulase producer in our past investigation [5].

\subsection{Biocatalysis of Agro-processing Wastes}

Cellulase was produced in solid-state fermentation using agroprocessing waste powder - mineral salt medium (MSM) as a production medium. The MSM was prepared by the procedure 
described earlier [6]. It contained the following (g/l): $\mathrm{Na}_{2} \mathrm{HPO}_{4} \cdot 2 \mathrm{H}_{2} \mathrm{O}$ - $1.1 \mathrm{~g}, \mathrm{NaH}_{2} \mathrm{PO}_{4} .2 \mathrm{H}_{2} \mathrm{O}-0.61 \mathrm{~g}, \mathrm{KCl}-0.3 \mathrm{~g}, \mathrm{MgSO}_{4} .7 \mathrm{H}_{2} \mathrm{O}-0.01 \mathrm{~g}$, and $\mathrm{pH}-7.0$. Different agro-processing waste powders (paddy straw, groundnut shell, rice bran, wheat bran, corn cob, and sawdust) were added individually to the production medium $(1 \% \mathrm{w} / \mathrm{v})$ and $\mathrm{pH}$ of this medium was fixed to 7.0 and make sterile in condition at $121^{\circ} \mathrm{C}$. This medium was inoculated with spore suspension of present organism and examined at room temperature for 6 days. Samples were withdrawn every $24 \mathrm{~h}$ and assayed for enzyme activity.

\subsection{Cellulase Assay}

Cellulase activity was assayed using the method described earlier by Wood and Bhat [7] with slight modifications. $0.5 \mathrm{ml}$ of crude extract was used as cellulase; $0.5 \mathrm{ml}$ of $1 \%$ carboxymethyl cellulose was used as substrate. One unit of cellulase enzyme activity is equal to the $\mu$ moles of glucose liberated per ml enzyme used per min under assay conditions.

\subsection{Factors Influencing the Cellulase Activity}

\subsubsection{Effect of incubation period (hours)}

To find out fermentation period required for highest production of cellulase, the present isolate was inoculated on MSM added with $1 \%$ rice bran, as this medium gives generally quick development and enzyme activity. The fermentations were done at $30^{\circ} \mathrm{C}$ for $144 \mathrm{~h}$ and the concentrates were examined for enzyme activity.

\subsubsection{Effect of temperature $\left({ }^{\circ} \mathrm{C}\right)$}

To decide the impact of temperature on enzyme activity, fermentation was done at various incubation temperatures ranging from $25^{\circ} \mathrm{C}$ to $50^{\circ} \mathrm{C}$. The samples were pulled back following $96 \mathrm{~h}$ and the concentrates were measured for cellulase activity.

\subsubsection{Effect of $\mathrm{pH}$}

To decide the ideal starting medium $\mathrm{pH}$ for actinomycetes development and enzyme generation, the medium $\mathrm{pH}$ was balanced from 5.0 to 11.0 utilizing buffering agents $(0.1 \mathrm{M} / \mathrm{L})$ and flasks were incubated at $40^{\circ} \mathrm{C}$ for $96 \mathrm{~h}$. The samples were pulled back after incubation time and unrefined concentrates were tested for enzyme activity.

\subsubsection{Effect of substrate concentration (g)}

Enzyme activity was studied by incorporating various concentrations of substrate $(\mathrm{g} / 100 \mathrm{ml}) 0.2,0.4,0.6$, and 0.8 to the production medium, and $\mathrm{pH}$ adjusted to 9.0. Then, flasks were inoculated with a spore suspension of the above-mentioned organism and incubated at $40^{\circ} \mathrm{C}$ for $96 \mathrm{~h}$ and the enzyme activity was tested.

\subsubsection{Effect of inoculum size ( $\mathrm{ml}$ )}

The spore suspension of the above organism was prepared by harvesting slants in $100 \mathrm{ml}$ of starch casein broth under sterile conditions. The inoculum sizes $(\mathrm{ml} / 100 \mathrm{ml}) 0.2,0.4,0.6$, and 0.8 were transferred to flasks containing production medium ( $\mathrm{pH}-9.0$, with $0.6 \mathrm{~g}$ of substrate) and inoculated flasks were incubated at $40^{\circ} \mathrm{C}$ for $96 \mathrm{~h}$ and the enzyme activity was assayed.

\subsubsection{Effect of carbon source}

Distinctive outer carbon sources such as fructose, glucose, maltose, and lactose were brought into the production medium at the level of $1 \%(\mathrm{w} / \mathrm{v})$. Under the previously mentioned conditions, the flasks were inoculated and incubated. Then, the cellulase activity was examined.

\subsubsection{Effect of nitrogen source}

Various nitrogen sources such as peptone, beef extract, yeast extract, and ammonium sulfate were supplied to the production medium at a level of $1 \%(\mathrm{w} / \mathrm{v})$ and the control was maintained with the absence of any nitrogen source. All investigations were done at previously mentioned cultural conditions and cellulase activity was tested.

\section{RESULTS AND DISCUSSION}

Cellulose degrading microorganisms distributed in the marine environment play an important role in mineralization of organic matter and thereby increasing the productivity of the sea. There were only few reports on the generation of cellulase by marine actinomycetes, and our literature survey revealed that this is the first report on marine S. fungicidicus producing cellulase.

\subsection{Biocatalysis of Agro-processing Wastes}

Bioconversion of agro waste biomass by actinomycetes is a potential sustainable approach to develop new products. In this research, several agro-processing wastes were utilized as substrates for the generation of cellulase. The results [Figure 1] revealed that $S$. fungicidicus strain RPBS-A4 produced maximum quantity of cellulase from rice bran $(6.59 \mathrm{U} / \mathrm{ml})$. Microorganisms in the environment degrade disposed agro-processing waste by biocatalysis so utilizing these cheap waste materials for producing high-value enzymes is a suitable waste management plan for cleaning the environment and reducing the production cost of enzymes in industry [8].

\subsection{Factors Influencing the Cellulase Productivity}

Cellulases have potential applications in food, feed, textile, fuel, and chemical industries. As of late various applications are being proposed and commercially applied for cellulase [9]. For this reason, the present strain had inspected for its capacity to use agro-processing waste deposits as a nutrient for enzyme production under the control of various factors. The physicosynthetic attributes of the fermentation medium assumed an imperative part in cellulase generation by S. fungicidicus RPBS-A4.

\subsubsection{Effect of incubation period (hours)}

The impact of various time interims on cellulase generation by $S$. fungicidicus RPBS-A4 was determined. At first, cellulase production $(1.75 \mathrm{U} / \mathrm{ml})$ was noted at $24 \mathrm{~h}$ of incubation, it was expanded to 12.29 $\mathrm{U} / \mathrm{ml}$ at $96 \mathrm{~h}$ of incubation and afterward it was diminished to 3.85 $\mathrm{U} / \mathrm{ml}$ at $144 \mathrm{~h}$ [Figure 2]. This demonstrates that incubation time prominently affected cellulase production by the strain and the ideal incubation time for cellulase generation is $96 \mathrm{~h}$. Cellulase activity of S. fungicidicus RPBS-A4 (12.29 U/ml) under the optimized conditions is especially greater than the activity of mentioned strains Streptomyces sp. BRC1 $(6.4 \mathrm{U} / \mathrm{ml})$ and BRC2 $(6.6 \mathrm{U} / \mathrm{ml})$ isolated from the soil of decomposed garden [3].

\subsubsection{Effect of temperature $\left({ }^{\circ} \mathrm{C}\right)$}

The highest cellulase production $(12.32 \mathrm{U} / \mathrm{ml})$ was observed at $40^{\circ} \mathrm{C}$ [Figure 3]. On increasing the temperature of the cellulase production was decreased to $9.77 \mathrm{U} / \mathrm{ml}$. Temperature assumes an essential part in the development of actinomycetes; under the ideal temperature, the development rate of $S$. fungicidicus RPBS-A4 was expanded, as the development rate expanded cellulase generation was additionally expanded. Chellapandi and Jani [3] declared that the highest quantity of enzyme was produced by Streptomyces sp. BRC1 and BRC2 in submerged fermentation at ideal temperature $26^{\circ} \mathrm{C}$, i.e. $7.1 \mathrm{U} / \mathrm{ml}$. Maximum cellulase activity of $S$. fungicidicus RPBS-A 4 at $40^{\circ} \mathrm{C}$ was better than the activity of revealed strain. This demonstrates the ideal 
temperature for high cellulase production by this strain is $40^{\circ} \mathrm{C}$, which is in accordance with the findings of McCarthy [10] who announced

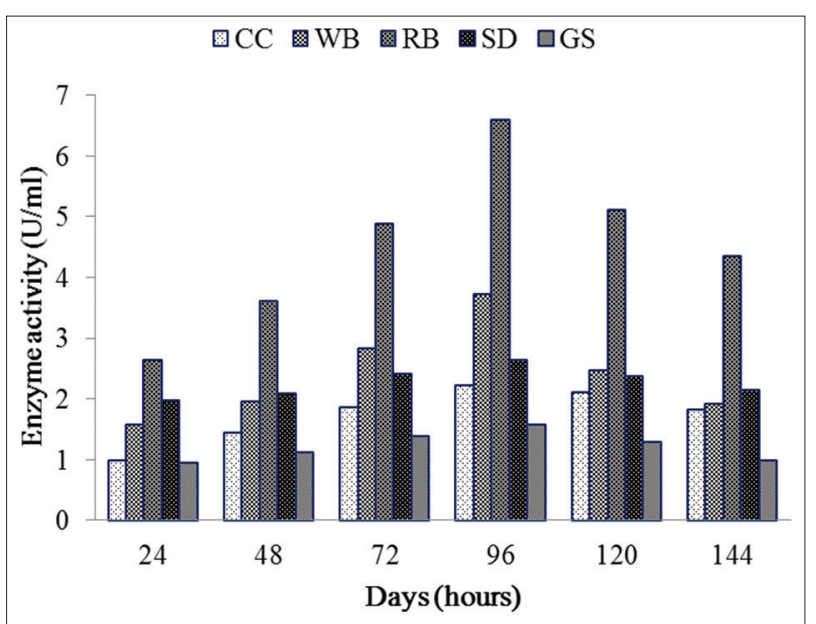

Figure 1: Biocatalysis of agro-processing waste for cellulase production by Streptomyces fungicidicus RPBS-A4 (CC: Corncob, WB: Wheat bran, RB:

Rice bran, SD: Sawdust, GS: Groundnut shell, and PS: Paddy straw).

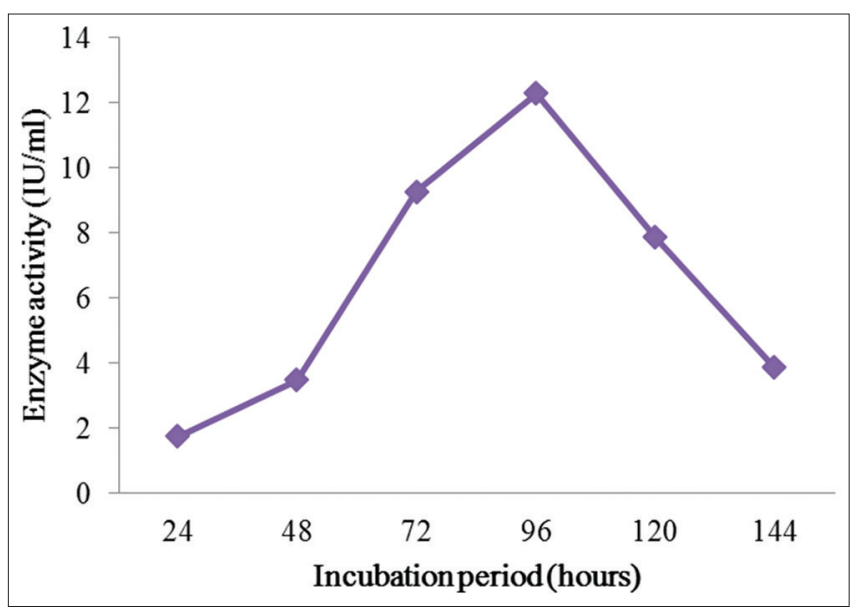

Figure 2: Effect of incubation period (hours) on cellulase production by Streptomyces fungicidicus RPBS-A4.

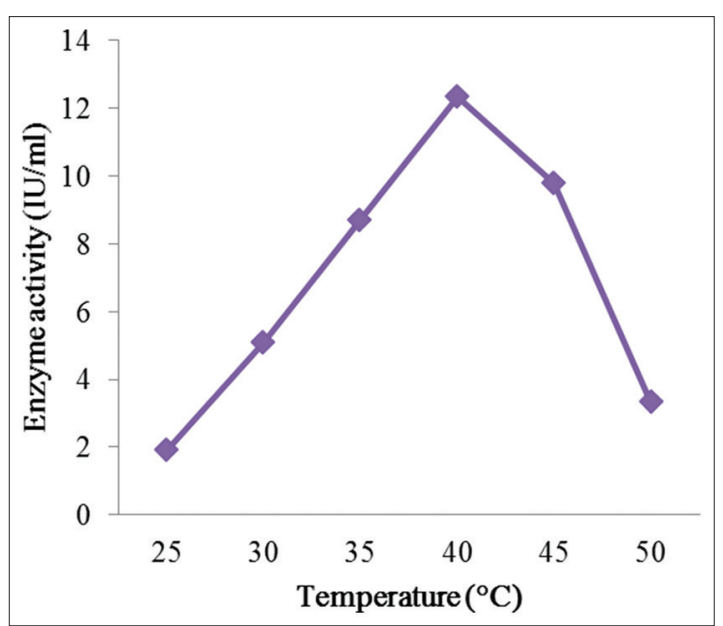

Figure 3: Effect of temperature on cellulase production by Streptomyces fungicidicus RPBS-A4. that an ideal temperature for enzyme activity is in the scope of $40-55^{\circ} \mathrm{C}$ for a few Streptomyces species.

\subsubsection{Effect of $\mathrm{pH}$}

The impact of $\mathrm{pH}$ on enzyme productivity by the isolate was determined. Cellulase generation was gone between 5.67 and 13.18 $\mathrm{U} / \mathrm{ml}$. The highest cellulase production of $13.18 \mathrm{U} / \mathrm{ml}$ was seen at $\mathrm{pH} 9.0$ and lowest cellulase production $5.67 \mathrm{U} / \mathrm{ml}$ was seen at $\mathrm{pH} 11.0$ [Figure 4]. This indicates that the ideal $\mathrm{pH}$ for high cellulase production by $S$. fungicidicus RPBS-A4 is 9.0.

\subsubsection{Effect of substrate concentration (g)}

The effect of substrate concentration on cellulase production by the present strain was examined at various substrate concentrations. The highest cellulase production $(12.64 \mathrm{U} / \mathrm{ml})$ was seen with $0.6 \mathrm{~g} / 100 \mathrm{ml}$ of a substrate (rice bran). After expanding or diminishing the substrate concentration cellulase production by $S$. fungicidicus RPBS-A4 was diminished to $9.55 \mathrm{U} / \mathrm{ml}$ [Figure 5]. This proves that the appropriate concentration is $0.6 \mathrm{~g}$ per $100 \mathrm{ml}$ of fermentation medium. Similarly, Immanuel [11] was used coir fiber powder as the substrate for the generation of cellulase by bacteria. They found that maximum quantity of cellulase $0.081,0.041$, and $0.023 \mathrm{U} / \mathrm{ml}$ at

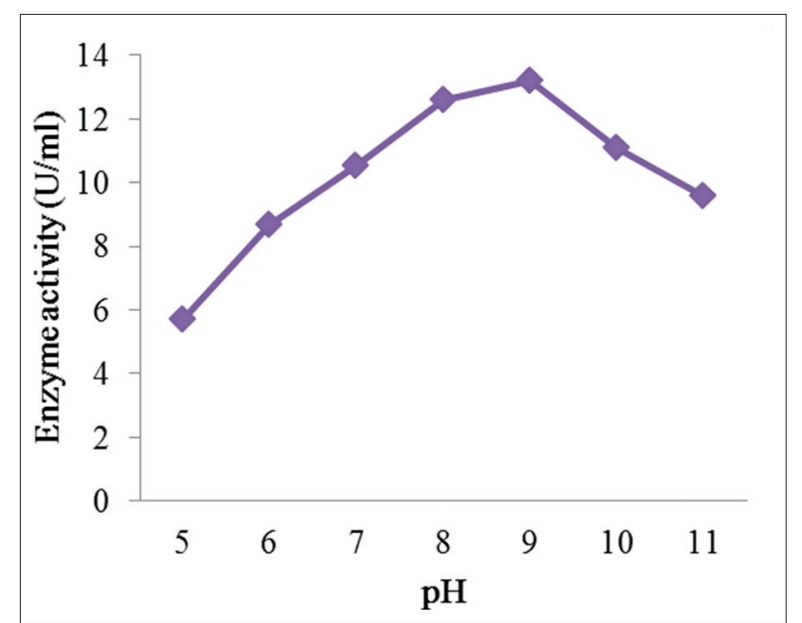

Figure 4: Effect of $\mathrm{pH}$ on cellulase production by Streptomyces fungicidicus RPBS-A4.

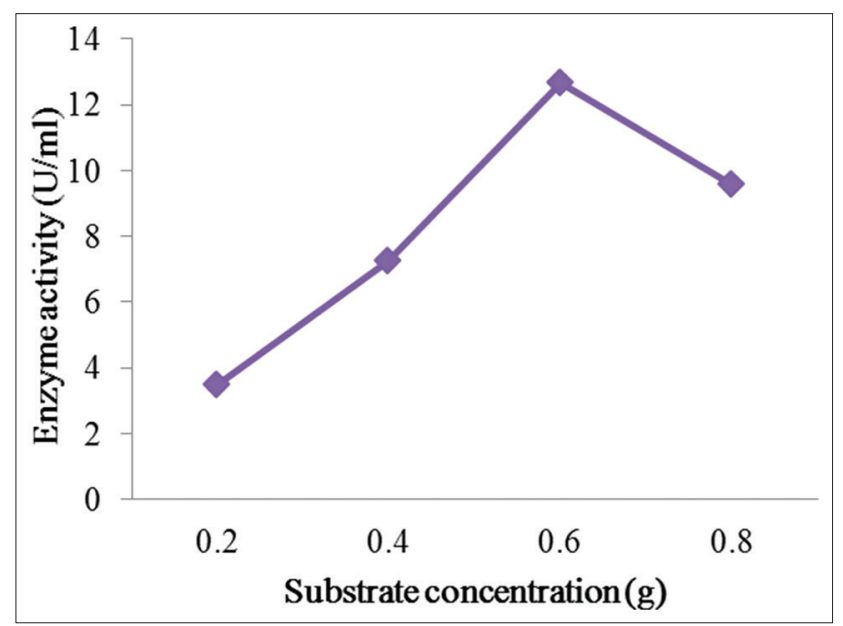

Figure 5: Effect of substrate concentration (g) on cellulase production by Streptomyces fungicidicus RPBS-A4. 
$1.5 \%$ concentration of substrate. The highest cellulase production of S. fungicidicus RPBS-A4 using rice bran was 150 times more than the above-mentioned strain.

\subsubsection{Effect of inoculum size ( $\mathrm{ml})$}

The inoculum concentration had a prominent effect on cellulase production. The cellulase showed maximum activity $(12.59 \mathrm{U} / \mathrm{ml})$ using $0.6 \mathrm{ml}$ inoculum [Figure 6]. Results obtained in the present investigation proposed that the ideal inoculum concentration is $0.6 / 100 \mathrm{ml}$ of fermentation medium for the generation of enzyme by S. fungicidicus RPBS-A4 in solid state bioprocessing. These outcomes are in accordance with an earlier report of cellulase generation by Bacillus circulans in solid state bioprocessing [6].

\subsubsection{Effect of carbon source (1\%)}

The impact of various carbon sources on cellulase generation by the marine isolate was resolved. The highest cellulase production (10.14 $\mathrm{U} / \mathrm{ml}$ ) was observed in the presence of maltose (external carbon source) [Figure 7]. The presence of additional carbon sources, glucose, and fructose was decreased the cellulase generation than the control. This indicates that the carbon source exist in the generation medium had assumed a key part, i.e., the more concentration of additional carbon source decreased the growth rate of $S$. fungicidicus RPBS-A4. Hence, there was no need of an external carbon source for cellulase production by this strain. Similar results were found when $1 \%$ glucose treated as an external carbon source in Bacillus subtilis [12].

\subsubsection{Effect of nitrogen source (1\%)}

The impact of various nitrogen sources on enzyme generation by $S$. fungicidicus RPBS-A4 was resolved. Results revealed that maximum production of cellulase $12.64 \mathrm{U} / \mathrm{ml}$ was observed when yeast extract was served as external nitrogen source [Figure 8]. These findings were very close to Bacillus cereus MRK1 producing cellulase in the presence of external nitrogen source as yeast extract [13].

\section{CONCLUSION}

In the present study, efforts were made to increase the enzyme production by modifying the nutritional conditions and $\mathrm{pH}$ of the fermentation medium. The results revealed that cellulase activity of $13.18 \mathrm{U} / \mathrm{ml}$ was seen under appropriate cultural conditions by $S$. fungicidicus strain RPBS-A4 are better than the prior revealed strains. Notwithstanding these, some extra properties such as external carbon source (maltose) and lower substrate fixation, less fermentation period for cellulase production showing the capability of the isolate to be utilized at profitable level in industries. An outline of the outcomes acquired demonstrates that solid-state fermentation of agro-processing waste deposits was appropriate to deliver minimal effort, high esteem item, i.e. cellulase by $S$. fungicidicus RPBS-A4. The ecological contamination caused by the disposal of cellulosic wastes, which are continuously added to the environment through the process of photosynthesis will also reduce by utilizing agro-processing waste as a sole carbon hotspot for the generation of cellulase.

\section{ACKNOWLEDGMENT}

The authors would like to thank the Department of Biotechnology and Environmental Sciences of Sri Venkateswara University, Tirupati, for providing required infrastructural facilities.

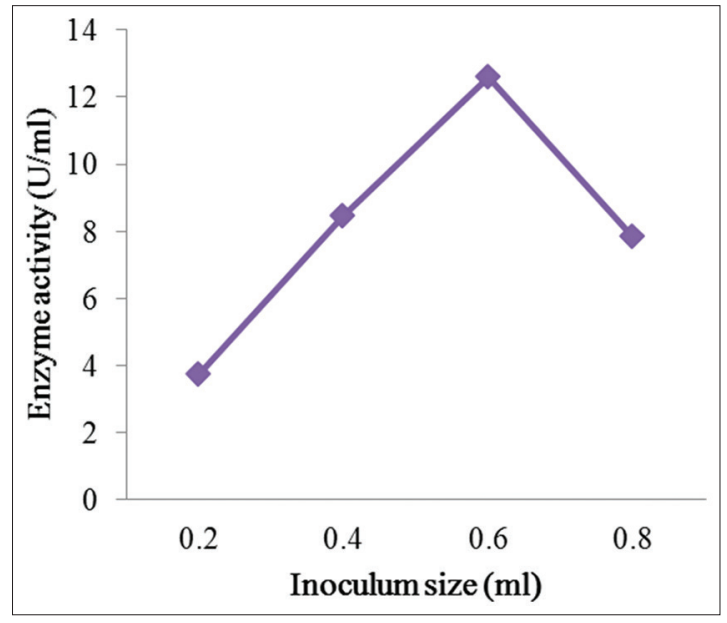

Figure 6: Effect of inoculum size (ml) on cellulase production by Streptomyces fungicidicus RPBS-A4.

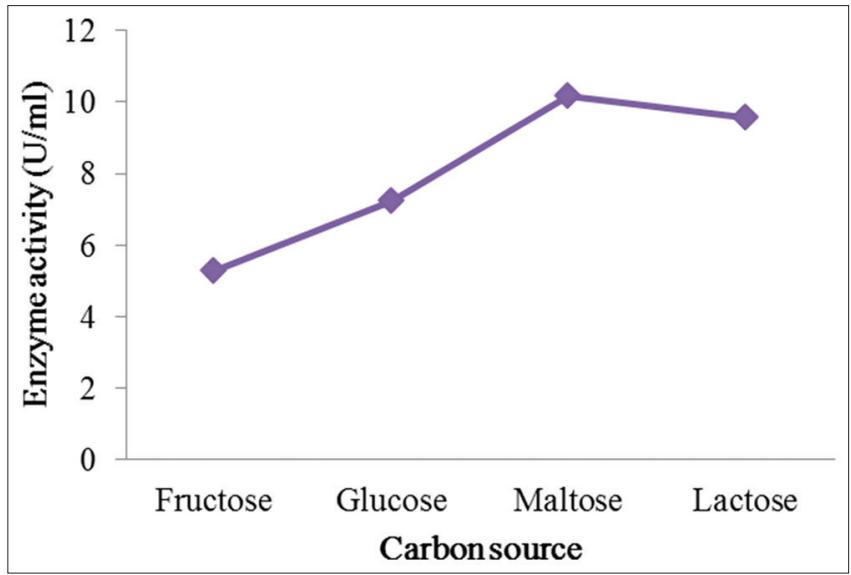

Figure 7: Effect of carbon source (1\%) on cellulase production by Streptomyces fungicidicus RPBS-A4.

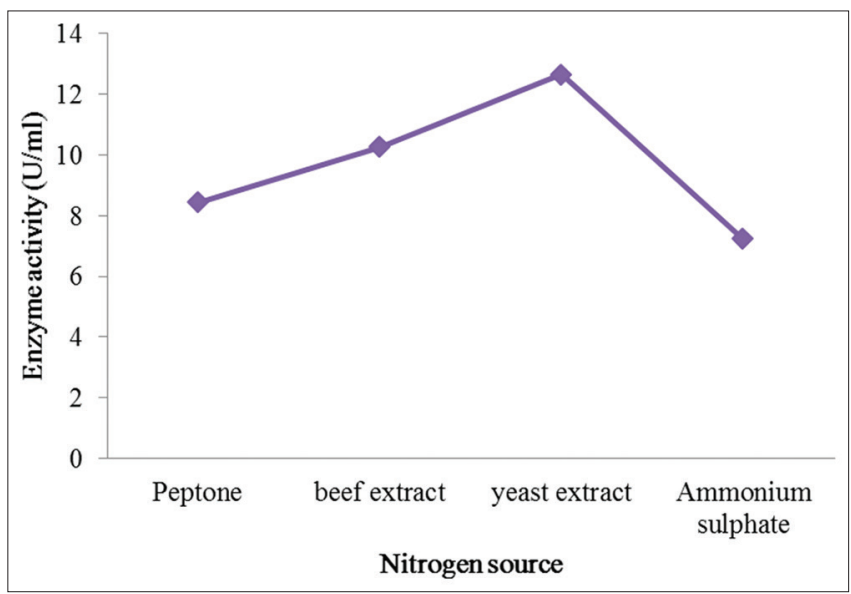

Figure 8: Effect of nitrogen sources on cellulase production by Streptomyces fungicidicus RPBS-A.

\section{REFERENCES}

1. Sadhu S, Maiti TK. Cellulase production by bacteria. Br Microbiol Res J 2013;3:235-58.

2. Vinogradova SP, Kushnir SN. Biosynthesis of hydrolytic enzymes 
during cocultivation of macro-and micromycetes. Appl Biochem Microbiol 2003;39:573-5.

3. Chellapandi P, Jani HM. Production of endoglucanase by the native strains of Streptomyces isolates in submerged fermentation. Braz J Microbiol 2008;39:122-7.

4. Pandey A, Selvakumar P, Carlos R, Nigam SP. Solid state fermentation for the production of industrial enzymes. Curr Sci 1999;77:149e62.

5. Rajanikanth A, Damodharam T. Screening of marine soils from bay of Bengal near Chirala coast of Andhra Pradesh for isolation of lipolytic actinobacteria and characterization of the most potent isolates. Int J Pharma Sci Res 2017;8:1000-10.

6. Singh AK, Maharana AK, Masih H, Kumar Y, Mishra SK. Production, optimization and purification of bacterial cellulase by solid state bioprocessing of agro biomass. Res J Pharm Biol Chem Sci 2012;3:975-8585.

7. Wood TM, Bhat KM. Method for measuring cellulose activities. In: Wood WA, Kellogg JA, editors. Methods in Enzymology Cellulose and Hemicellulose. New York: Academic Press; 1998. p. 87-112.

8. Pandey A, Soccol CR, Mitchell D. New developments in solid state fermentation: I-bioprocesses and products. Process Biochem
2000;35:1153-69.

9. Bhat MK, Bhat S. Cellulose degrading enzymes and their potential industrial applications. Biotechnol Adv 1997;15:583-620.

10. McCarthy AJ. Lignocellulose degrading actinomycetes. FEMS Microbiol 1987;46:145-63.

11. Immanuel G, Dhanusha R, Prema P, Palavesam A. Effect of different growth parameters on endoglucanase enzyme activity by bacteria isolated from coir retting effluents of estuarine environment. Int $\mathbf{J}$ Environ Sci Technol 2006;3:25-34.

12. Bai S, Kumar MR, Kumar DJ, Balashanmugam P, Kumaran MD, Kalaichelvan PT. Cellulase production by Bacillus subtilis isolated from cow dung. Arch Appl Sci Res 2012;4:269-79.

13. Kumar DJ, Poovai PD, Kumar CL, Saroja Y, Manimaran A, Kalaichelvan PT. Optimization of Bacillus cereus MRK1 cellulase production and its bio stoning activity. Pharm Lett 2012;4:881-8.

\section{How to cite this article:}

Akurathi R, Thoti D. Biocatalysis of agro-processing waste by marine

Streptomyces fungicidicus strain RPBS-A4 for cellulase production. J App Biol Biotech. 2018;6(1):38-42. DOI: 10.7324/JABB.2018.60107 